\title{
Correction to: Interaction between Fusarium oxysporum f. sp. cubense and Radopholus similis can lead to changes in the resistance of banana cultivars to Fusarium wilt
}

\author{
Anelita de Jesus Rocha • Mileide dos Santos Ferreira • Leandro de Souza Rocha • \\ Saulo A. S. Oliveira • Edson Perito Amorim • Eduardo S. G. Mizubuti • Fernando Haddad
}

Published online: 8 September 2020

(C) The Author(s) 2020

\section{Correction to: Eur J Plant Pathol. https://doi.org/10.1007/s10658-020-02081-y}

This erratum is published due to:

a. Retrospective Open Access was requested by authors after publication of the article.

b. Incorrect name placement in original article.

Anelita Jesus de Rocha, Mileide Santos dos Ferreira and Leandro Souza de Rocha.

should read as:

Anelita de Jesus Rocha, Mileide dos Santos Ferreira and Leandro de Souza Rocha.

The online version of the original article can be found at https://doi.org/10.1007/s10658-020-02081-y

A. de Jesus Rocha $\cdot$ M. dos Santos Ferreira

Universidade Federal do Recôncavo da Bahia, Rua Rui Barbosa, 710 Centro, CEP, Cruz das Almas, Bahia 44380-000, Brazil

L. de Souza Rocha · S. A. S. Oliveira • E. P. Amorim •

F. Haddad $(\bowtie)$

Embrapa Mandioca e Fruticultura, Rua Embrapa, s/n, CP 007 ,

Centro, CEP, Cruz das Almas, Bahia 44380-000, Brazil

e-mail: fernando.haddad@embrapa.br

\section{E. S. G. Mizubuti}

Universidade Federal de Viçosa, Av. Peter Henry Rolfs, s/n,

Campus Universitário, Viçosa, Minas Gerais, Brazil
The original publication has been thus corrected.

\begin{abstract}
Open Access This article is licensed under a Creative Commons Attribution 4.0 International License, which permits use, sharing, adaptation, distribution and reproduction in any medium or format, as long as you give appropriate credit to the original author(s) and the source, provide a link to the Creative Commons licence, and indicate if changes were made. The images or other third party material in this article are included in the article's Creative Commons licence, unless indicated otherwise in a credit line to the material. If material is not included in the article's Creative Commons licence and your intended use is not permitted by statutory regulation or exceeds the permitted use, you will need to obtain permission directly from the copyright holder. To view a copy of this licence, visit http://creativecommons.org/licenses/by/4.0/.
\end{abstract}

